\title{
Could the impaired intention of ethical investment be recovered?
}

\author{
Chiung-Yao Huang*, Yu-Cheng Lin** and Chiung-Hui Chen*
}

\begin{abstract}
The environmental pollution caused by Advanced Semiconductor Engineering in October 2013 in Taiwan highlighted the fact that foreign investors tend to support the classical economic ideas of arbitrage and shareholder wealth maximization, which is in conflict with the fact that institutional investors in the current global capital market lean towards the stakeholder theory in ethical investments. Will local investors' decision-making also be influenced by differences in the perceived ethics of negative environmental corporate social responsibility (ECSR)? Compared to the remedial measures implemented by British Petroleum for the 2010 Deepwater Horizon oil spill, Advanced Semiconductor Engineering, another international corporation, decided to not respond to any news regarding the toxic wastewater incident. In contrast, Advanced Semiconductor Engineering only made clearer promises after extreme public pressure. This study investigated whether remedial measures for negative ECSR are an important factor influencing investors' decisions. The purpose is to clarify the interactions among perceived moral intensity of negative ECSR, the implementation of remedial measures, and the intention of ethical investment. An experimental design was employed to test the hypotheses. The results indicated that perceived moral intensity has a significant negative impact on the intention of ethical investment. The implementation of remedial measures for negative ECSR affects investors' intent to invest. Finally, positive ECSR remedial measures also serve as a key moderating variable in the relationship between perceived moral intensity and the intention of ethical investment. This study clarified whether the provision of remedial mechanisms can effectively recover or maintain investor investment intent when companies experience negative ECSR.
\end{abstract}

Keywords: Negative Environmental Corporate Social Responsibility (ECSR), moral intensity, remedial measures, ethical investment intention

Received 6 July 2015. Accepted 17 November 2015

\section{INTRODUCTION}

(7 here's nothing wrong with making money; it's how you make the money that counts.' Ethical investment or socially responsible investment is broadly defined as the integration of personal values, social considerations, and economic factors into investment decisions. Financial return remains an important outcome, but it is not the sole criterion driving investments; ethical concerns are also included (Jones, 1991; Michelson, Wailes, Van Der Laan, \& Frost, 2004). Standardized or conventional investment focuses on higher financial returns whereas ethical investment focuses not only on financial

* Department of Accounting, National Yunlin University of Science and Technology, Taiwan, R.O.C.

** Department of Banking and Finance, National Chi Nan University, Taiwan, R.O.C.

Corresponding author: linyc@ncnu.edu.tw 
returns but also on the integrity of personal values and social considerations. Better performing ethical funds attract both ethical investors and conventional investors (McLachlan \& Gardner, 2004). Investors are also becoming more active in engaging in concrete investments by supporting corporate social and environmental responsibilities in order to use that power to influence manager decisionmaking (Simister \& Whittle, 2013).

Beyond Beauty-Taiwan From Above, a documentary that spent 3 years documenting Taiwan from an aerial perspective, was released in Taiwan in October 2013. In the first 3 days, it broke the record for most tickets sold during an opening weekend for a Taiwanese documentary and won Best Documentary at the 50th Golden Horse Awards in 2013. The culprit behind the polluted river captured in the documentary was none other than the world's leading semiconductor manufacturer Advanced Semiconductor Engineering Inc. (ASE; TWSE: 2311, NYSE: ASX). The media exposed this, attracting the attention of the local environmental protection bureau, which found that ASE's K7 plant has been discharging wastewater into the Houjin River. In December 2013, the local environmental protection bureau fined ASE's K7 plant and Taiwanese environmental protection and labor groups rallied local farmers and residents in protest and to demand that the plant be shut down. As a result, the $\mathrm{K} 7$ plant received an order to cease operation. In terms of the capital market, the environmental pollution incident aroused public indignation and caused ASE to be fined by the environmental protection bureau. From then on, the company's stock prices continued to plummet. However, after determining its fundamentals to be good, foreign investors seized the opportunity to invest large amounts and overbought up to 233,669 shares over eleven trading days, with trading fees accounting for $-40 \%$ of the daily trading amount. These foreign capital investments contradicted the responses of the local government and the public. The foreign investors do not live in the polluted area, and therefore made investments in the capital market to gain profits, whereas the local government and people protested from the perspective of stakeholders.

Taiwan is a developing country that exports high-tech products. The heavy metal contamination caused by high-tech products has presented the Taiwanese government and public with the choice between economic development and an environmental crisis. In terms of local corporations, due to the globalization of the Taiwanese capital market, corporations have the advantage of access to loans in the securities market. Also, due to the industrial cluster effect, industries have competitive advantages in the global market. Environmental pollution in Taiwan has highlighted the fact that foreign investments tend to support the classical economic ideas of arbitrage and shareholder wealth maximization, which is in conflict with the fact that institutional investors in the current global capital market lean towards the stakeholder theory in ethical investments. Will local investors' decision-making also be influenced by differences in the perceived ethics of negative environmental corporate social responsibility (ECSR)? In addition, are the environmental remedial measures adopted by corporations in response to contamination incidents important factors that influence the decision-making of investors? For instance, British Petroleum (BP; LSE: BP, NYSE: BP) is an energy exploration and development company with relatively high environmental risks that operates in the petroleum industry. In light of the $2010 \mathrm{BP}$ oil spill, BP apologized multiple times and took almost full responsibility for cleaning up the mess. BP also immediately proposed an emergency preparation plan and established an investigation team 2 days after the incident to begin investigating on their own. Moreover, BP organized the Gulf Coast Restoration Organization, which was responsible for restoring the ecosystem and communities as well as long-term crisis management. On the other hand, ASE, also a global leader, chose not to issue a statement when the news of their role in the wastewater pollution came to light. They only gave clear commitments due to tremendous public pressure. There was a sharp contrast between the two ways these companies dealt with negative ECSR. Therefore, this study investigated whether the remedial measures adopted by corporations after negative ECSR events change investors' decisions to invest. The purpose is to clarify the interactions among perceived moral intensity of negative ECSR, the 
implementation of remedial measures for negative ECSR, and the intention of ethical investment. As the economic consequences affect the security of the company finance structure and cash flow stability, this can help companies decide ECSR policy and what response measures should be taken at times of negative ECSR.

This study adopted an experimental design to verify hypotheses. General investors were represented by 139 university students enrolled in the financial statement analysis course. In the course, students were taught about ethical investment and then divided into a test group and a control group. The two different groups of students received a report on negative ECSR by company A. The report the control group received did not include any remedial measures after the event, while the experimental group received a report that included the remedial measures adopted after the event occurred. Scales and questionnaires were used to measure participants' perceived moral intensity and their willingness to invest in company A. The study also employed a four-stage question requesting that students give their opinions regarding company $\mathrm{A}$ as a basis for qualitative data.

Empirical results from two-way analysis of variance showed that as environmental awareness increases, investors show more concern for whether corporations are capable of reducing environmental impacts while creating new products and maintaining the ability to effectively manage risk. Therefore, the higher the investors' perceived moral intensity for negative ECSR, the more investors are willing to make ethical investments. However, when negative ECSR events occur, it is important to promptly prevent failures from happening again via appropriate mechanisms to help repair trust. Showcasing the company's competencies, good intentions, and sincerity can also effectively restore and maintain investors' trust, thus reducing the impact that perceived moral intensity for negative ECSR has on investment intention.

The following section discusses the relevant theoretical background, while Section III describes the experiment conducted in this study. Section IV discusses the results, and finally, a summary of this study and a conclusion are provided in Section V.

\section{THEORETICAL BACKGROUND}

\section{Negative ECSR, shareholder wealth maximization, and the stakeholder theory}

The abnormal climate caused by human damage to the environment has brought about frequent major disasters in recent years, which poses a big threat to global economic development and human survival (Parmesan, 2006); thus, society has high expectations for corporations to fulfill ECSR. Visser (2008) pointed out that developed countries have formulated more relevant regulations, but developing countries lack complete compulsory regulations for corporations and mainly face social and environmental crises. This study focused on the electronics industry, the core of Taiwan's economic development, due to its pivotal role as original design manufacturer and original equipment manufacturer of electronic products in Taiwan. Due to the international supply chain's continuous advocacy of green products policies, requests for cooperative partners to fulfill corporate social responsibility (CSR), and the development of the financing environment of the global capital market, whether companies can transform ECSR into a strategic action is associated with their international competition. In addition, better stakeholder engagement and transparency around CSR performance, are important in reducing capital constraints (Cheng, Ioannou, \& Serafeim, 2014).

Saeidi, Sofian, Saeidi, Saeidi, and Saaeidi (2015) find the positive effect of CSR on firm performance is due to the positive effect CSR has on competitive advantage, reputation, and customer satisfaction. Besides, Mackey, Mackey, and Barney (2007)also advocated that corporations devoted to CSR can develop goodwill capital or reduce the benefits of risk. On the contrary, negative CSR runs the risk of being fined by competent authorities and lawsuits, and could even incite boycotts from consumers and 
society, resulting in damages to corporate revenue and profits (Brown \& Dacin, 1997). Even though CSR investments are the current trend by institutional investors in the global capital market, one of the world's leading manufacturers of semiconductors, ASE, was heavily punished and ordered by competent authorities to stop operations following its release of highly acidic wastewater laden with heavy metals that contaminated thousands of hectares of farmland in December 2013. ASE provides 43,000 jobs in Taiwan, accounting for $84 \%$ of the local employees where it operates. In 2013, their consolidated revenue reached NT\$219.862 billion. However, after ASE's negative ECSR event occurred, the Taiwanese securities market saw unethical investments from foreign financial institutions. In the media, ASE has been shown to have repeatedly caused environmental pollution and aroused public anger. After stock prices began to rapidly decline, foreign investors overbought at a low price. This study collected news reports on foreign investment and found that foreign investors believed that ASE's pollution would only affect their short-term revenues and were still optimistic about the company's future growth and profits, thus maintaining the buy rating on the stock. With this good investment fundamentals rating, ASE's foreign capital after their negative ECSR was exposed reached $76.07 \%$, becoming the greatest drive behind ASE stock prices. Lastly, due to the demand for CSR in the supply chain and social and stakeholder criticism, ASE promised to improve its environmental behavior in the long run.

The aforementioned phenomenon highlights the fact that investments from foreign investors tend to support shareholder wealth maximization, which is in conflict with the ethical investments in mainstream stakeholder theory preferred by institutional investors in the global capital market. The second topic in this study is whether corporations should adopt remedial measures or a passive response when facing negative ECSR. In other words, this study investigated the effect of remedial measures on investment intention during negative ECSR. Lastly, this study further examined whether a company's remedial measures can effectively regulate the negative impact of perceived moral intensity on investment intention after negative ECSR events occur. An experimental design was used to provide evidence explaining investors' decision-making process when facing a dilemma regarding ethical investment. Moreover, the Taiwanese securities market is a shallow-plate form of investment. The continuous outbreak of negative CSR in recent years has affected Taiwan's international competitiveness and threatened the survival of local companies; therefore, how investor shareholding supports ethical investment and encourages corporations to fulfill CSR has significant importance in the building of a sound capital market.

\section{Research conceptual model development}

This study observed the incentives for foreign investors in the capital market to overbuy in companies which they have determined to have good fundamentals and have experienced negative ECSR in order to highlight the fact that foreign investments support the shareholder wealth maximization theory, which is in conflict with the ethical investment of institutional investors in the global capital market. In other words, the theoretical construct is that after experiencing negative ECSR, conflict arises in investment strategy between shareholder wealth maximization and stakeholder theory. Investors can buy or dump stocks to show their support or disapproval of a company's social and environmental responsibility. Companies can also adopt active or passive remedial measures when facing negative ECSR. Therefore, corporate remedial measures are an important factor affecting investor decisions.

As Taiwan is a shallow-plate capital market, foreign investments play a decisive role. The research question of this study focused on the ethical investment of local investors, specifically whether they will follow foreign investors' overbuying after negative ESCR. The purpose was to clarify the correlations between investors' perceived moral intensity for a company facing negative ECSR, the response 
measures of the company, and corporate ethical investment intention. As the economic consequences affect the security of the company finance structure and cash flow stability, the research goal was to help companies decide what response measures should be taken at times of negative ECSR. The hypotheses put forth in this study are stated below.

\section{Perceived moral intensity, remedial measures, and ethical investment intention}

Perceived moral intensity refers to the perceived importance of moral issues among investors in a specific scenario and is a key factor that influences ethical investment decision-making (Jones, 1991). When investors perceive a higher degree of damage to be caused by a corporation's negative ECSR, more people will agree that this behavior is illegal, the possibility of this behavior causing actual damage will be high, the consequences will follow within a short amount of time and affect more people, and people will more likely consider themselves victims. This increases the perceived moral intensity of investors and thereby raises their intent to make ethical investments. Therefore, they are more likely to remove this investment target from their future investment portfolio (McLachlan \& Gardner, 2004).

In addition, Valor, de la Cuesta, and Fernandez (2009) also found that $40 \%$ of questionnaire responders claimed they are willing to sacrifice some financial benefits to invest in ethical corporate stocks. Mackey, Mackey, and Barney (2007) maintained that engaging in CSR activities can develop goodwill capital or reduce the benefits of risk. On the contrary, negative CSR runs the risk of being fined by competent authorities and lawsuits, and could even incite boycotts from consumers and society, thereby resulting in damages to corporate revenues and profits (Brown \& Dacin, 1997). An increasing number of investors are actively striving to influence the decision-making power of corporations by supporting investment behavior that involves fulfilling both social and environmental responsibilities (Simister \& Whittle, 2013). In summary, investors' degree of perceived moral intensity for negative ECSR has a significant negative impact on future investment intentions.

Because business operations consume a large amount of resources and discharge waste, and because of people's indifference toward these issue in the past, the resulting disastrous changes have caused environmental protection to become a common concern in the world (Banyte, Brazioniene, $\&$ Gadeikiene, 2010). As a result, how corporations incorporate environmental protection and environmental management into their operations in order to develop innovative eco-friendly products and environmentally friendly work environments, as well as maintain good relationships with stakeholders, has become a key factor for the survival and development of corporations.

According to the aforementioned, balancing profits and additional investments that influence the environment has become a strategic resource investment that increases a corporation's competitive advantage (Drucker, 1984; Porter \& Kramer, 2006). For example, a good reputation can bring about social identification as well as enhance brands, improve corporate images, raise stock prices, and create corporate value (Porter \& Kramer, 2006). From the perspective of enlightened self-interest, corporations place importance on ECSR as it can save resources, reduce costs, and create a positive reputation in the long run (Porter \& Kramer, 2006). Corporations often maintain conversations with stakeholders in order to gain the opportunity for recognition and innovation, improve internal operating procedures, obtain external operating legal status, and effectively manage risks (Porter \& Kramer, 2006). By emphasizing ECSR and sharing ethical values and beliefs with employees, corporations can increase employee promises and attract better human resources. In other words, as awareness of environmental protection increases, employees, shareholders, consumers, and other corporate stakeholders participate and share the values and belief in a triple bottom line - the financial, social, and environmental performance of corporations (Banyte, Brazioniene, \& Gadeikiene, 2010). 
Even though organizational reputation and trustworthiness require continual, long-term investments, negative ECSR instantly impacts the corporation's reputation and trustworthiness, raises doubts about their technical competence, motivation, and integrity, and even arouses distrust regarding their sustainable survival, thus reducing investors' willingness to invest in the corporation's stock. However, Weun, Beatty, and Jones (2004) held that despite the difficulty in repairing distrust between corporations and stakeholders and restoring of reputations, these ends can still be achieved by effectively implementing remedial measures. According to the above, when corporations encounter negative ECSR, implementing remedial measures results in significantly higher investment intention than if no measures were enacted.

\section{Remedial measures for negative ECSR reduce the impact perceived moral intensity has on future investment intention}

Weun, Beatty, and Jones (2004) maintained that effective remedial measures for negative ECSR include distrust regulation and trustworthiness demonstration. The former forms restrictions and controls adherence procedures to ensure that failure does not reoccur in order to repair trust. The latter emphasizes that corporate actions can provide new evidence that trustworthy corporations are still competent, good-willed, and integral; this includes apologies, compensation, information transparency, and sustainable investments.

When a corporation implements remedial measures in response to negative ECSR, the message it sends out is that the corporation will adopt relevant procedures and reduce the recurrence of similar events. In addition, by publicly promising and implementing compensation plans, corporations provide new evidence that demonstrates their goodwill and competencies (Barone, Miyazaki, \& Taylor, 2000; Ellen, Mohr, \& Webb, 2000). Moreover, future ECSR performance of corporations will exceed social expectations (Brown \& Dacin, 1997) and change public opinion of corporate values (Lafferty \& Goldsmith, 1999; Mohr \& Webb, 2005). Therefore, partial trustworthiness can be regained during the trust repair process, thereby reducing investors' degree of moral intensity caused by recurrence of negative ECSR events in the future. This study proposed the following hypothesis based on the review above.

Hypothesis: Investors with higher (lower) perceived moral intensity toward negative ECSR have lower (higher) intent to invest in a corporation. However, adopting remedial measures can alleviate the negative effect that perceived moral intensity has on investment intention.

\section{EXPERIMENTAL METHOD}

\section{Research design}

This study used an experimental design to investigate the hypotheses. Investors' perceived moral intensity (high/low) and corporations' remedial measures (yes/no) for negative ECSR were set as independent variables. The dependent variable was the participants' intent to invest in the corporation. In this study, ASE's environmental pollution incident was referenced for an imaginary company A; participants were asked to complete the questionnaire created by Singhapakdi, Vitell, and Kraft (1996) after reading the case and were measured on their perceived moral intensity (high/low). In terms of remedial measures, clustering was used to provide information to participants in different groups regarding whether or not company A implemented remedial measures after negative ECSR events. Regarding investment intention, participants were required to read, understand, and contemplate the effect company A's financial performance, CSR performance, and implementation (or lack) of remedial measures after the ECSR event have on their investment intention. 


\section{Participants}

A total of 139 university students from the Colleges of Management who were currently enrolled in courses on financial statement analysis in central Taiwan represented potential general investors. Among the participants, $69.06 \%$ had first- or second-hand experience with stock investments and $65.47 \%$ planned to invest in stocks within five years. A total of 139 questionnaires were distributed to participants who returned them after completion. Excluding thirteen ineffective questionnaires, 126 effective questionnaires were included in the analysis for a response rate of $90.65 \%$.

\section{Procedures}

The 139 participants were first randomly divided into 26 groups of five or six people. Then, 13 groups were chosen as the experimental group in which company A implemented remedial measures after the negative ECSR events. The remaining 13 groups served as the control group in which company A did not implement any remedial measures. The case information provided to all participants included a basic financial analysis report for the imaginary company A designed based on ASE, a professional analysis report on the negative ECSR event, a perceived moral intensity scale, an investment willingness scale, an open-ended ethical dilemma questionnaire, and a basic information questionnaire. The following describes in detail the experiment design and procedures.

First, the participants were instructed via a video on ethical investments. The teacher pre-recorded the teaching materials in a video introducing the concept of ethical investments which included three major topics. Topic 1: Why do shareholders provide the funds required for business operation? Topic 2: How do shareholders evaluate corporate value? Using company A as an example, the teacher introduced the corporate value analytical process, including 'industrial analysis-Porter five forces analysis,' 'corporate competitive strategy analysis-SWOT analysis,' 'corporate economic analysisfinancial reports and appendixes,' and 'corporate social and environmental analysis.' Topic 3: The teacher introduced the shareholder perspective (i.e., the theory of maximizing shareholder value proposed by classical economics scholar Friedman (1970)) and stakeholder perspective (i.e., the stakeholder concept by Bowen (1953), the 'Father of Corporate Social Responsibility') using the question, 'Should corporations implement corporate social responsibility?'

Second, participants were asked to read the professional analysis report for company A's negative ECSR event. This professional analysis report was divided into two scenarios. The different groups were given different analysis reports in order to manipulate whether remedial measures were implemented by company A after the event. The analysis report the control group received stated that company A did not implement any remedial measures after the negative ECSR event occurred. The report included the following: (1) the key problem: company A dumped toxic wastewater into local rivers and was therefore ordered by the environmental protection bureau to shut down; (2) the influences on communities, residents, employees, and the supply chains; (3) the number and a comparison of negative CSR events by company A and a business competitor that were exposed by the media during that month; (4) the rank of the main stakeholders that were influenced due to the negative CSR performances by company A and the business competitor; and (5) information regarding purchases in stock exchange market by foreign investors before and after the incident occurred; the content described public outrage and response to company A's environmental pollution incident, the continued decline of stock prices, and foreign investors continued to purchase stock. The professional analysis report given to the experimental group received described the implementation of remedial measures. In addition to information identical to that mentioned above, the report also included the remedial measures company A implemented in response to the negative ECSR event. (1) Remedial measures: company A promised to donate NT\$100 million to the local community every year for the 
following 30 years, to improve facilities to prevent pollution in order to resume operations as soon as possible, to fund US\$300 million in green bonds to construct green buildings and factories and invest in pollution-free facilities, and to not recruit anymore contract workers; (2) a comparison of the number of negative CSR events by company A and the business competitor one to six months after being exposed by the media.

Third, the participants were requested to fill out a perceived moral intensity scale, investment willingness scale, ethical dilemma open-ended questionnaires, and basic information questionnaire.

Last, each group discussed and expressed their opinions on ethical dilemma problems. Group discussion on ethical dilemmas was divided into four phases: (1) If I were an investor, would I follow foreign institutional investors and buy the dips on company A after negative ECSR occurred? (2) When negative ECSR occurred in company A, what expectations do stakeholders have in regards to whether or not I follow foreign institutional investors and buy the dips on company A? (3) When negative ECSR occurred in company A, if I follow foreign institutional investors and buy the dips on company A, will it have a personal affect on me or stakeholders? (4) If I had the chance to rethink my investment decision, would I choose to follow foreign institutional investors and buy the dips on company A after negative ECSR occurred? A representative from each group compiled and recorded common opinions in the group. Each group representative then shared the opinions within their group using lucky chain, and the teacher drew conclusions.

\section{Measurement}

\section{Dependent variable}

In this study, investors' intention of ethical investment was used as the main dependent variable, and was measured by asking participants their willingness to purchase stock in company A and their willingness to continue holding stock in company A $(\alpha=0.882)$. All items were measured on a 7-point Likert scale from strongly disagree (1) to strongly agree (7). In other words, the larger the number, the higher the participants' investment intention.

\section{Independent variables}

The main independent variables of this study were perceived moral intensity and remedial measures. The perceived moral intensity variable included the four dimensions from Singhapakdi, Vitell, and Kraft (1996), including the magnitude of consequences, temporal immediacy, probability of effect, and concentration of effect. This variable ultimately considered participants' perceived damage incurred by the stakeholder. Therefore, perceived moral intensity was defined as ethical decision-makers' perceived damage incurred by stakeholders with regards to the negative ECSR. The greater the perceived potential damage, the higher the moral intensity. All items were measured on a 7-point Likert scale from strongly disagree (1) to strongly agree (7). In other words, the higher the score, the higher the perceived moral intensity. The standard for differentiating participants' perceived moral intensities was their average scores. Participants with scores higher than the average were classified into a high perceived moral intensity group, while those with lower scores were classified into a low perceived moral intensity group.

In terms of variable measurement for remedial measures, this study randomly separated the participants into experimental and control groups. The two groups were given different professional analysis reports in order to manipulate the 'implementation of remedial measures' variable. The analysis report given to the control group stated that company A did not implement any remedial measures after the negative ECSR event occurred. The analysis report given to the experimental group included the same information as was given to the control group with additional information on company A implementing remedial measures after the negative ECSR event. 


\section{Control variables}

In terms of control variables, gender and personal moral relativism were used as the control factors for investment willingness. Schueth (2003) found that gender is an important variable influencing the ethical investment of American investors, and the same results were found in Australia (Tippet, 2001). Therefore, this study considered the effect gender has on ethical investment intention and the incorporated control variables. Forsyth (1992) also asserted that ethics refers to the integrated conceptual system of an individual's moral beliefs, attitudes, and values. In the face of ethical problems, an individual will have different intentions and behaviors depending on the preference of these ethics; therefore, personal ethics will affect an individual's ethical judgment and behavior. Individuals' moral relativism was also used as a control variable in this study. Relativism was measured using a 7-point Likert scale developed by Forsyth (1980).

\section{RESULTS}

Table 1 includes the means, standard deviations, and correlations for the study variables.

\section{Manipulation checks}

In terms of manipulation, a 7-point Likert scale was used to examine participants' responses to the statement 'I am evaluating if I considered the effect environmental CSR events have on stakeholders when investing in company A's stocks,' with 1 representing strongly disagree and 7 representing strongly agree. The mean of this item was 5.58 and only $8.4 \%$ of the participants answered that they did not consider the effect of environmental CSR events on stakeholders when investing in stocks. This result indicated that when answering their investment intention, participants not only considered the basic information on company A's finances but also read in detail the company's negative ECSR event professional analysis report.

\section{Test of our hypothesis}

The main hypothesis of this study was that investors with a higher perceived moral intensity toward negative ECSR have lower investment intention, and vice versa. However, companies with negative ECSR can adopt remedial measures to alleviate the effect that perceived moral intensity has on

Table 1. Mean, standard deViations, and correlations for research Variables

\begin{tabular}{|c|c|c|c|c|c|c|}
\hline Variables & Mean & $S D$ & 1 & 2 & 3 & 4 \\
\hline 1. Gender ${ }^{a}$ & 0.333 & 0.473 & - & & & \\
\hline 2. Relativism & 4.811 & 0.610 & 0.042 & - & & \\
\hline 3. Remedial measures ${ }^{b}$ & 0.476 & 0.501 & 0.000 & 0.145 & - & \\
\hline 4. Perceived moral intensity ${ }^{c}$ & 0.492 & 0.502 & $-0.225^{\star \star}$ & -0.096 & -0.048 & - \\
\hline 5. Intention of ethical investment & 4.754 & 1.326 & $0.310 * * \star$ & 0.133 & $0.478^{\star \star \star}$ & $-0.406^{\star \star}$ \\
\hline
\end{tabular}

Notes.

${ }^{\text {a Female }}=0$, Male $=1$

${ }^{\mathrm{b}}$ Have not remedial measures $=0$, have remedial measures $=1$

${ }^{\mathrm{c}}$ Low $=0$, High $=1$

${ }^{\star *} p<.05 ;{ }^{* \star *} p<.01$ 
Table 2. Descriptive statistics and test of hypothesis

Panel A: descriptive statistics - intention of ethical investment

\begin{tabular}{|c|c|c|c|c|c|}
\hline \multirow[b]{2}{*}{ Condition } & \multicolumn{4}{|c|}{ Perceived moral intensity } & \\
\hline & $N$ & Low & $n$ & High & \\
\hline $\begin{array}{l}\text { Have not remedial measures } \\
\text { Have remedial measures }\end{array}$ & $\begin{array}{l}32 \\
32\end{array}$ & $\begin{array}{l}5.000(0.803) \\
5.563(0.471)\end{array}$ & $\begin{array}{l}34 \\
28\end{array}$ & $\begin{array}{l}3.353(1.379) \\
5.250(1.118)\end{array}$ & \\
\hline \multicolumn{6}{|c|}{ Panel B: ANOVA model of intention of ethical investment } \\
\hline Source of variation & SS & $d f$ & MS & F-statistic & $p$-value \\
\hline Gender & 8.751 & 1 & 8.751 & 9.168 & 0.003 \\
\hline Relativism & 0.089 & 1 & 0.089 & 0.093 & 0.761 \\
\hline Perceived moral intensity & 22.155 & 1 & 22.155 & 23.210 & 0.000 \\
\hline Remedial measures & 47.311 & 1 & 47.311 & 49.564 & 0.000 \\
\hline Perceived moral intensity $\times$ remedial measures & 11.390 & 1 & 11.390 & 11.565 & 0.001 \\
\hline Error & 114.546 & 120 & 0.955 & & \\
\hline
\end{tabular}

Panel C: results of regression analysis testing for hypothesis

\begin{tabular}{lccr}
\hline & \multicolumn{2}{c}{ Intention of ethical investment } \\
\cline { 2 - 4 } Variables & Coefficient & SD & T-statistic \\
\hline Intercept & $5.310^{\star \star \star}$ & 0.763 & 6.961 \\
Gender & $0.578^{\star \star \star}$ & 0.191 & 3.028 \\
Relativism & -0.045 & 0.148 & -0.305 \\
Perceived moral intensity & -0.254 & 0.254 & -1.001 \\
Remedial measures & $1.853^{\star \star \star}$ & 0.258 & 7.191 \\
Perceived moral intensity $\times$ remedial measures & $-1.221^{\star \star \star}$ & 0.359 & -3.401 \\
Adjusted $R^{2}$ & 0.457 & & \\
\hline
\end{tabular}

Note. ${ }^{\star \star *} p<.01$

investment intention. Panel A in Table 2 shows the descriptive statistics of participants' willingness to invest in company A with regards to remedial measures and perceived moral intensity. Panel A shows that participants had a higher willingness to invest when company A implemented remedial measures regardless of whether their perceived moral intensity was high or low.

Panel B in Table 2 shows the statistical analysis of the hypothesis using two-way analysis of variance. The results showed that perceived moral intensity reached statistical significance $(p=.000$, two-tailed), meaning that the level of perceived moral intensity reached a statistically significant difference for participants' investment willingness. The remedial measures variable reached statistical significance ( $p=.000$, two-tailed), indicating that negative ECSR companies' implementation of remedial measures reached statistical significant difference for participants' investment willingness. Most importantly, the cross-multiplication effect of perceived moral intensity and remedial measures reached statistical significance ( $p=.001$, two-tailed), supporting this study's hypothesis. This indicates that investors with higher perceived moral intensity toward negative ECSR companies had lower investment intention, and vice versa. However, companies with negative ECSR can adopt remedial measures to alleviate the effect that perceived moral intensity has on investment intention. This result is presented in Figure 1. 


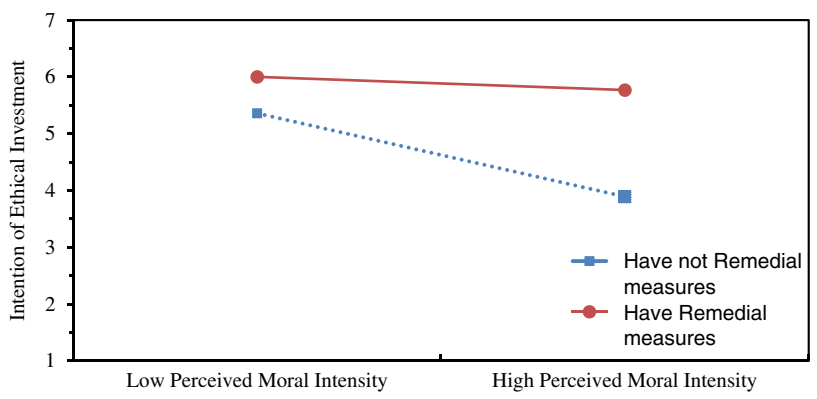

Figure 1. The JOINT EFFECTS OF PERCEIVED MORAL INTENSITY AND REMEDIAL MEASURES ON INTENTION OF ETHICAL INVESTMENT

Panel $\mathrm{C}$ in Table 2 shows the statistical results from regression analysis. The results showed that the gender coefficient $(0.578)$ reached statistical significance $(p=.003$, two-tailed $)$, indicating that under normal circumstances, male participants had higher investment intention compared to female participants. The remedial measures coefficient (1.853) reached statistical significance $(p=.001$, twotailed), indicating that under normal circumstances, participants had higher investment intention when company A implemented remedial measures compared to when they were not implemented. Finally, the perceived moral intensity and remedial measures cross-multiplication coefficient $(-1.221)$ reached statistical significance $(p=.001$, two-tailed), indicating that investors with higher perceived moral intensity towards negative ECSR companies had lower investment intention, and vice versa. However, companies with negative ECSR events can adopt remedial measures to alleviate the effect that perceived moral intensity has on investment intention.

\section{Additional support for our theory: qualitative analysis}

Qualitative analysis data on participants considering investing in company A was collected and participants were questioned in four phases. The purpose of the first question was to understand participants' intuitive moral judgment by asking them, 'If I were an investor, would I follow foreign institutional investors and buy the dips on company A?' The purpose of the second question was for participants to observe whether their decisions are consistent with the expectations of others by asking, 'Do stakeholders have expectations whether or not I follow foreign institutional investors and buy the dips on company A?' The third question involved the participants' decision-making process, externalizing the potential influences of their decision. The participants were asked, 'If I follow foreign institutional investors and bought the dips on company A, would it affect myself or stakeholders?' These three phases guided participants in their contemplation of shareholder value maximization and stakeholders. After expanding participants' thinking and the impacts thereof, they could gain an understanding of the factors involved in ethical investment dilemmas. Thus, participants were asked, 'If given the chance rethink my investment decision, would I follow foreign institutional investors and buy the dips on company A?'

The results showed that the participants' answers were divided into three main types. (1) Consideration for the damages incurred by stakeholders and willingness to give up personal economic benefits. (2) Consideration for company A's remedial actions and personal economic benefits. (3) Formulation of actions solely based on personal economic benefits. The following are examples of participants' opinions. 


\section{Decision-making types}

Consideration of the possible damages to stakeholders' interests willingness to give up personal economic interests.

Based on the negative impact company A has caused to society and environment, investors should not invest in company $\mathrm{A}$.

Based on economic benefits, I would buy stock in company A. However, considering the negative impact on society and the environment, even if it meant gaining profit in the short run, other problems could occur that would cause the company to shut down in the future.

Therefore I would not invest in company A.

Based on economic benefits, I would buy stock in company A's. However, considering the negative impact on society and the environment, I would not invest in company A.
Consideration of both company A's remedial actions and personal economic benefits

The reasons why investors are willing to invest is because they believe that company A will immediately adopt remedial measures to salvage their reputation and maintain long-term growth.

Based on the negative impact company A has caused to society and the environment, I would not invest in company A.

However, if company A implements remedial measures and makes improvements, I believe that they would continue to grow in the long run.

Therefore, I would invest in company A.

Based on economic benefits, I would buy stock in company A. However, I will decide if I would to hold or sell the stock based on the company's future CSR performance.
Formulation of actions solely based on personal economic benefits

Purchasing stock in company $A$ is expected to bring in profits; considering personal economic benefits, I would buy stock in company A.

The purpose of investing is to gain profit; considering personal economic benefits, I would buy stock in company A.
The purpose of investing is to gain profit; investing can also give company $\mathrm{A}$ sufficient funds to initiate improvement measures. Therefore, I would buy stock in company A.

\section{DISCUSSION}

\section{Implications of research}

The results showed that the perceived moral intensity of investors with regards to negative ECSR significantly affects their ethical investment intention and that when companies with negative ECSR implement remedial measures, the negative effect perceived moral intensity has on ethical investment intention can be alleviated. The findings of the qualitative data analysis are consistent with those of a study by Clark, Feiner, and Viehs (2014). That is, when investors make investments, they make decisions based on stakeholder rights rather than shareholder rights, which means they are more likely 
to give up personal economic benefits considering the damages done to stakeholders due to specific events. During the decision-making process, investors who consider the damages inflicted upon stakeholder rights and personal economic benefits are willing to give up part of their economic benefits. Furthermore, once companies face ECSR that resulted in a negative impact on society and the environment, investors believe that the company will immediately adopt remedial measures to redeem themselves and regain their reputation and maintain long-term growth; thus, investors will still be willing to invest in company A. In other words, some investors, after company A experienced negative ECSR, will still decide to buy stock in company A on the premise that they implement remedial measures. The aforementioned findings indicate that considering corporate cost of equity capital and stable stock prices, once companies encounter negative ECSR, they should adopt remedial measures in order to alleviate the negative impact on the company's equity financing. In addition, because the corporation would have adopted remedial measures, they are able to reduce the impact of investors' deliberations over the economic and ethical considerations of investing in negative ECSR companies.

The analysis results showed that when investors place more emphasis on stakeholders' interests, they are more likely to make decisions that meet ethical standards when faced with ethical investment dilemmas. In other words, they will consider the damages that could be inflicted upon stakeholders' interests and some investors would be willing to give up personal economic interests. This finding is consistent with the conclusion made by Peifer (2014), that companies with ethical behavior are more likely to attract patient capital. Moreover, economic motivation can reduce the loyalty of socially responsible investors and ethical motivation induces socially responsible investors' loyalty. Therefore, from the perspective of financing, corporations should view CSR as a strategic investment to benefit the establishment of their financing advantages.

In addition, as developing and developed countries differ in terms of system environment, culture, and development, aside from the existing variations of CSR issues (Chapple \& Moon, 2005; Arya \& Zhang, 2009), investor activities in emerging markets are also different from those in developed countries. For example, markets are less efficient and exhibit herding behavior. Empirical studies on the effect and role CSR plays in the capital market are lacking (Dhaliwal, Li, Tsang, \& Yang, 2011; Dhaliwal, Radhakrishnan, Tsang, \& Yang, 2012). Taiwan's capital market is a shallow-plate investment environment. Under the global CSR trend, strengthening investors' stakeholder awareness in order to exhibit ethical investment is an important issue in ethical investment education in developing countries. Therefore, this study primarily investigated the effect of perceived moral intensity on future investment intentions. From the perspective of the competent authority and ethical education, this study suggests that strengthening investors' perceived morals to facilitate investors' motivation for ethical investment aids the development of the capital market. Thus, the research conclusions are practical.

Last, this study also has made theory contributions. The primary contribution to the literature on ethical investments is the confirmation that in the face of negative ECSR events, investors' perceived moral intensity significantly affects their investment intent. However, when a company with negative ECSR implements remedial measures, the negative effect that perceived moral intensity has on ethical investment intent can be reduced. The results of this study indicate that a given corporation should initiate remedial measures for negative ECSR in order to relieve the negative impact on the corporation's equity financing and to stabilize stock prices. In addition, adopting remedial measures can relieve the economic and ethical dilemma investors face when considering investing in companies with negative ECSR.

Second, the experimental methods used in this study analyzed the correlation between general investors' perceived moral intensity and ethical investment intention when local leading corporations conduct negative ECSR. This experimental design can directly reflect investors' behavior and reactions better than collecting second-hand market transactions data. Collection of qualitative data also reflects how the perspectives of stakeholders influence their investment decision-making process when investors face ethical investment dilemmas. 


\section{Limitations and future research}

Future studies can reference these findings when focusing on news events, using communications theory to further investigate the effect of information diffusion and how companies should respond to CSR events in order to reduce the damage to corporate value and stock price fluctuation caused by investors' negative reactions. Also, incorporating traditional behavioral finance can enrich the literature on CSR and the capital market. For example, investigation into the frequency of CSR events (single CSR event or multiple CSR events), CSR crisis management (active or passive), and response time (the continuity of media exposure (duration), exposure (time), connection (breadth)) and their influence on the capital market, including stock price fluctuation, corporate stockholding, individual stockholding, abnormal returns, and the effect on future profits are all important in research on topics on the capital market.

In addition, group discussions can be viewed as a socialization process. In other words, individuals discuss and learn social regulations and expectations to gain a further understanding of stakeholder rights. Therefore, future studies can conduct experiments to collect statistics and examine the four-phase question method applied in this study. (1) First ask about immediate decisions; (2) then ask about the expectations of stakeholders; (3) then contemplate the influences that the original decision would have on their self and stakeholders; (4) lastly, re-think the decision to note any changes. Teaching through group discussions could strengthen moral intensity, thereby affecting investment decision-making and thus investment intention. This teaching approach was used to verify whether investors' perspectives could be shifted from shareholder value maximization to stakeholder perspective through education. The managerial implications of this study indicate that based on the classical economics perspective of wealth maximization and arbitrage in behavioral finance, education on CSR can be used to strengthen the stakeholder perspective in order to reduce dilemmas in investors' moral decision-making processes and reinforce ethical investment intention.

\section{ACKNOWLEDGEMENT}

We would like to thank JMO editors and the anonymous reviewers for their helpful comments and suggestions.

\section{References}

Arya, B., \& Zhang, G. (2009). Institutional reforms and investor reactions to CRS announcements: Evidence from an emerging economy. Journal of Management Studies, 46(7), 1089-1112. doi:http://10.1111/j.1467-6486.2009.00836.x.

Banyte, J., Brazioniene, L., \& Gadeikiene, A. (2010). Expression of green marketing developing the conception of corporate social responsibility. Inzinerine Ekonomika-Engineering Economics, 21(5), 550-560.

Barone, M. J., Miyazaki, A. D., \& Taylor, K. A. (2000). The influence of cause-related marketing on consumer choice: Does one good turn deserve another? Journal of the Academy of Marketing Science, 28(2), 248-262. doi:10.1177/ 0092070300282006.

Bowen, H. R. (1953). Social responsibilities of the businessman. New York: Harper and Row.

Brown, T. J., \& Dacin, P. A. (1997). The company and the product: Corporate associations and consumer product responses. The Journal of Marketing, 61(1), 68-84.

Chapple, W., \& Moon, J. (2005). Corporate social responsibility (CSR) in Asia: A seven-country study of CSR web site reporting. Business \& Society, 44(4), 415-441. doi:http://10.1177/0007650305281658.

Cheng, B., Ioannou, I., \& Serafeim, G. (2014). Corporate social responsibility and access to finance. Strategic Management Journal, 35(1), 1-23. doi:http://10.1002/smj.2131.

Clark, G. L., Feiner, A., \& Viehs, M. (2014). From the stockholder to the stakeholder: How sustainability can drive financial outperformance. SSRN, doi:http://dx.doi.org/10.2139/ssrn.2508281.

Dhaliwal, D. S., Li, O. Z., Tsang, A., \& Yang, Y. G. (2011). Voluntary nonfinancial disclosure and the cost of equity capital: The initiation of corporate social responsibility reporting. The Accounting Review, 86(1), 59-100. doi:http:// 10.2308/accr.00000005. 
Dhaliwal, D. S., Radhakrishnan, S., Tsang, A., \& Yang, Y. G. (2012). Nonfinancial disclosure and analyst forecast accuracy: International evidence on corporate social responsibility disclosure. The Accounting Review, 87(3), 723-759. doi:http://10.2308/accr-10218.

Drucker, P. F. (1984). Converting social problems into business opportunities: The new meaning of corporate social responsibility. California Management Review, 26(2), 53-63.

Ellen, P. S., Mohr, L. A., \& Webb, D. J. (2000). Charitable programs and the retailer: Do they mix? Journal of Retailing, 76(3), 393-406. doi:http://dx.doi.org/10.1016/S0022-4359(00)00032-4.

Forsyth, D. (1992). Judging the morality of business practices: The influence of personal moral philosophies. Journal of Business Ethics, 11(5-6), 461-470. doi:http://10.1007/BF00870557.

Forsyth, D. R. (1980). A taxonomy of ethical ideologies. Journal of Personality and Social psychology, 39(1), 175.

Friedman, M. (1970). The social responsibility of business is to increase its profits. September 13. The New York Times Magazine, SM17.

Jones, T. M. (1991). Ethical decision making by individuals in organizations: An issue-contingent model. The Academy of Management Review, 16(2), 366-395. doi:http://10.2307/258867.

Lafferty, B. A., \& Goldsmith, R. E. (1999). Corporate credibility's role in consumers' attitudes and purchase intentions when a high versus a low credibility endorser is used in the Ad. Journal of Business Research, 44(2), 109-116. doi:http://dx.doi.org/10.1016/S0148-2963(98)00002-2.

Mackey, A., Mackey, T. B., \& Barney, J. B. (2007). Corporate social responsibility and firm performance: Investor preferences and corporate strategies. The Academy of Management Review, 32(3), 817-835. doi:http://10.5465/ amr.2007.25275676.

McLachlan, J., \& Gardner, J. (2004). A comparison of socially responsible and conventional investors. Journal of Business Ethics, 52(1), 11-25. doi:http://10.1023/B:BUSI.0000033104.28219.92.

Michelson, G., Wailes, N., Van Der Laan, S., \& Frost, G. (2004). Ethical investment processes and outcomes. Journal of Business Ethics, 52(1), 1-10. doi:http://10.1023/B:BUSI.0000033103.12560.be.

Mohr, L. A., \& Webb, D. J. (2005). The effects of corporate social responsibility and price on consumer responses. Journal of Consumer Affairs, 39(1), 121-147. doi:http://10.1111/j.1745-6606.2005.00006.x.

Parmesan, C. (2006). Ecological and evolutionary responses to recent climate change. Annual Review of Ecology, Evolution, and Systematics, 37(1), 637-669. doi:http://10.1146/annurev.ecolsys.37.091305.110100.

Peifer, J. (2014). Fund loyalty among socially responsible investors: The importance of the economic and ethical domains. Journal of Business Ethics, 121(4), 635-649. doi:http://10.1007/s10551-013-1746-7.

Porter, M. E., \& Kramer, M. R. (2006). Strategy and Society: The link between competitive advantage and corporate social responsibility. Harvard Business Review, 84(12), 78-92.

Saeidi, S. P., Sofian, S., Saeidi, P., Saeidi, S. P., \& Saaeidi, S. A. (2015). How does corporate social responsibility contribute to firm financial performance? The mediating role of competitive advantage, reputation, and customer satisfaction. Journal of Business Research, 68(2), 341-350. doi:http://dx.doi.org/10.1016/j.jbusres.2014.06.024.

Schueth, S. (2003). Socially responsible investing in the United States. Journal of Business Ethics, 43(3), 189-194. doi:10.1023/A:1022981828869.

Simister, J., \& Whittle, R. (2013). Ethical investment and portfolio theory: Using factor analysis to select a portfolio. Journal of Mathematical Finance, 3(1), 145-152. doi:http://10.4236/jmf.2013.31A014.

Singhapakdi, A., Vitell, S. J., \& Kraft, K. L. (1996). Moral intensity and ethical decision-making of marketing professionals. Journal of Business Research, 36, 245-255. Retrieved from http://dx.doi.org/10.1016/0148-2963(95)00155-7.

Tippet, J. (2001). Performance of Australia's ethical funds. Australian Economic Review, 34(2), 170-178. doi:http:// 10.1111/1467-8462.00186.

Valor, C., de la Cuesta, M., \& Fernandez, B. (2009). Understanding demand for retail socially responsible investments: a survey of individual investors and financial consultants. Corporate Social Responsibility and Environmental Management, 16(1), 1-14. doi:http://10.1002/csr.172.

Visser, W. (2008). Corporate social responsibility in developing countries. In A. Crane, A. McWilliams, D. Matten, J. Moon, \& D. Siegel (Eds.), The Oxford handbook of corporate social responsibility (pp. 473-479). Oxford: Oxford University Press.

Weun, S., Beatty, S. E., \& Jones, M. A. (2004). The impact of service failure severity on service recovery evaluations andpost-recovery relationships. Journal of Services Marketing, 18(2), 133-146. doi:http://doi:10.1108/ 08876040410528737. 